\title{
The Chemical Modification of Protease Isolated from Locale Bacteria Isolate Bacillus subtilis ITBCCB148 with Nitrophenolcarbonate-Polyethylene Glycol (NPC-PEG)
}

\author{
Yandri (Corresponding author), Tati Suhartati, Dian Herasari \& Sutopo Hadi (Corresponding author) \\ Department of Chemistry, University of Lampung, Bandar Lampung 35145 Indonesia \\ E-mail: yandrias@unila.ac.id, sutopohadi@unila.ac.id
}

Received: May 30, 2011

Accepted: July 28, 2011

doi:10.5539/mas.v5n4p253

\begin{abstract}
The research aims to study the effect of chemical modification on the stability of protease enzyme from a local bacteria isolate $B$. subtilis ITBCCB148 with NPC-PEG. The result showed that the native enzyme has optimum $\mathrm{pH}$ and temperature of 6.5 and $60^{\circ} \mathrm{C}$, respectively. The stability test of the native protease at $\mathrm{pH} 6.5$ and temperature $60^{\circ} \mathrm{C}$ for 360 minutes produce the following results: the residual activity of $5.75 \%, \mathrm{t}^{1} / 2=84.5 \mathrm{~min}$., $\mathrm{k}_{\mathrm{i}}$ $=0.0082 \mathrm{~min}^{-1}$, and $\Delta \mathrm{G}_{\mathrm{i}}=106.508 \mathrm{~kJ} \mathrm{~mol}^{-1}$. The modified enzyme with NPC-PEG $(33 \%, 42 \%$, and $75 \%)$, showed that the optimum $\mathrm{pH}$ did not changed, however, the optimum temperature shifted from $60^{\circ} \mathrm{C}$ to $65^{\circ} \mathrm{C}$. The stability tests of the modified enzyme with NPC-PEG have increased of $2.06 ; 2.24$; and 2.31 times, respectively, than that of the native one. The decrease of ki, the increase of $\mathrm{t}^{1} / 2$ and $\Delta \mathrm{G}_{\mathrm{i}}$ of the modified enzymes with NPC-PEG demonstrated that upon modification, the enzyme became more stable. This might due to rigidity increase of the modified enzyme, so the active structure of the enzyme is maintained and is protected from unfolding process.
\end{abstract}

Keywords: B. subtilis ITBCCB148, Protease, Chemical modification, NPC-PEG

\section{Introduction}

Enzyme is a biocatalyst widely used in many industries due to its catalytic power which is in general by far much higher than a synthetic catalyst. According to Chaplin and Bucke enzyme has high specifity, speed up specific chemical reaction without side product, high productivity, and the final product is not contaminated so reducing the purification cost and environmental damage (Chaplin and Bucke, 1990).

One of the enzymes widely used in industrial sectors is protease. This enzyme catalyzes the breaking of the peptide bond in protein molecule to produce oligopeptide or amino acid (Rao et al., 1998). This enzyme is widely used both in food industries such as bread maker, beer, cheese and meat softener; and non-food industries such as detergent, medical product, synthesis of organic compound as well as pulp and paper industries (Vieille and Zeikus, 1996).

The enzyme required by industrial sector is a thermostable enzyme which is an enzyme that can work optimum in the temperature range of $60^{\circ}-125^{\circ} \mathrm{C}$ (Vieille and Zeikus, 1996) and at wider $\mathrm{pH}$ range. However, these two characters are usually not owned by most of the enzymes as they normally work at physiological condition and are not stable at high temperature and extreme $\mathrm{pH}$ (Goddette et al., 1993). To overcome these problems, the proper method is needed to increase the thermal stability of the enzyme. Mozhaev and Martinek (1984) proposed that the stabilization of enzyme obtained from mesophilic microbe was a preferred method to obtain stable enzyme, as direct isolation of enzyme from thermophilic microbe has some weaknesses such as the design of specific bioreactor and required new processing method (Janecek, 1993) which are not easily accessible.

Three methods are normally used to increase the stability of an enzyme, i.e. immobilization, chemical modification and directed mutagenesis. Of these methods, chemical modification is preferable as immobilization methods have problems of mass transfer inhibition of immobile matrix which can cause the decrease of binding activity and enzyme reactivity, whereas directed mutagenesis requires complete information about primer structure and complete three dimension structure (Mozhaev and Martinek, 1984).

Yang et al. (1996) have successfully performed chemical modification on subtilisin enzyme with activated-PEG and the results showed that the modified enzyme has half-life higher at all $\mathrm{pH}$ and temperature tested than that of native enzyme. Yandri (2004) has also done chemical modification on $\alpha$-amylase obtained from locale bacteria isolate $B$. subtilis ITBCCB148 using CC-PEG and NPC-PEG and has successfully increased the thermal stability of the enzyme 2-4 times compared to the native enzyme. He also observed that the modified enzyme worked at much wider $\mathrm{pH}$ range, between $\mathrm{pH}$ 4.5-9.0. Yandri et al. (2008) have also successfully carried out chemical modification on protease obtained from locale bacteria isolate B. subtilis ITBCCB148 using CC-PEG and the result was an increase in the thermal stability of protease 2-3 times. The modified enzyme also has wider $\mathrm{pH}$ range than the native enzyme, i.e.6.0-9.0. Based on the results obtained by previous researchers, we reported the 
first chemical modification on protease obtained from Indonesian locale bacteria isolate $B$. subtilis ITBCCB148 using NPC-PEG.

\section{Experiment}

\subsection{Starting Materials}

NPC-PEG and other chemicals used were purchased from Sigma Aldrich and used without further purification. Local bacteria isolate B. subtilis ITBCCB148 was obtained from Microbiology Laboratory, Chemical Engineering Department, Bandung Institute of Technology, Bandung, Indonesia. Buffer $\mathrm{pH}$ was measured at the temperature of use, and the $\mathrm{pH}$ reported is that at the temperature of the incubation.

\subsection{Production of protease}

The production of the enzyme was done using fermentation media as following: peptone $0.5 \%$, yeast extract $0.15 \%$, glucose $0.036 \%$, and $\mathrm{NaCl} 0.25 \%$ (Yandri et al., 2007).

\subsection{Purification of protease}

The purification of protease enzyme is done in few steps: the separation of enzyme liquid from the cell with cold centrifugation to get the raw enzyme extract, precipitation with ammonium sulphate, ion exchange column chromatography and molecule filtration column chromatography (Yandri et al., 2007; Yandri et al., 2008).

\subsection{Protease activity test and protein content determination}

The protease activity test was done based on the modified of Kunitz method (Yamaguchi et al., 1982). Protein content determination was done based on the method by Lowry et al. (1951).

\subsection{The modification of native enzyme with NPC-PEG}

$2 \mathrm{~mL}(0.15 \mathrm{mg} / \mathrm{mL})$ of native protease was placed in $8 \mathrm{~mL}$ vial wheaton containing $0.5 \mathrm{mg}$ activated-PEG in 2 $\mathrm{mL}$ borate buffer $(0.1 \mathrm{M} \mathrm{pH} \mathrm{8.0)}$. The molar ratio of PEG to native protease enzyme were 5:1; 10:1 and 15:1. The solution mixtures were stirred for $3 \mathrm{~h}$ at room temperature (Hernaiz et al., 1999).

\subsection{Determination of modification degree}

Determination of modification degree was done based on the method used by Synder and Sobocinski (1975) and as follows: $0.1 \mathrm{~mL}$ of modified enzyme was dissolved into $0.9 \mathrm{~mL}$ borate buffer $(\mathrm{pH} \mathrm{9.0)}$ and then was added with $25 \mu \mathrm{l} 0.3 \mathrm{M}$ TNBS. The mixture was then shaken and left it at room temperature for $30 \mathrm{~min}$. The standard solution was made with the same composition but using the native enzyme, while the blank solution contained 1 $\mathrm{mL}$ borate buffer $0.1 \mathrm{M} \mathrm{pH} 9$ and $25 \mu 10.3 \mathrm{M}$ TNBS. The absorbance was measured at the $\lambda_{\max } .420 \mathrm{~nm}$.

\subsection{Determination of optimum temperature before and after the modification}

To know the optimum temperature, the variations of temperature used were $50 ; 55 ; 60 ; 65$ and $70^{\circ} \mathrm{C}$, and then followed by the measurement of enzyme activity with Kunitz method (Yamaguchi et al., 1982).

\subsection{Thermal stability test and stability of the enzyme $\mathrm{pH}$ before and after the modification}

The enzyme thermal stability before and after the modification was done by measuring the residual activity of the enzyme after being incubated for $0,60,120,180,240$, and 300 min optimum $\mathrm{pH}$ and temperature based on the method applied by Yang et al. (1996).

\subsection{Determination of half-life $\left(t^{1 / 2}\right), k_{i}$ and $\Delta G_{i}$.}

Determination of $k_{\mathrm{i}}$ value (rate constant of thermal inactivation) of native enzyme and the modified enzyme was done using the first order of inactivation kinetics equation (Equation 1) (Kazan et al., 1997):

$\ln (\mathrm{Ei} / \mathrm{E} 0)=-\mathrm{k}_{\mathrm{i}} \mathrm{t}$

The denaturation energy change $\left(\Delta \mathrm{G}_{\mathrm{i}}\right)$ of the native and modified enzymes was done using the Equation (2) (Kazan et al., 1997):

$$
\Delta \mathrm{G}_{\mathrm{i}}=-\mathrm{RT} \ln \left(\mathrm{k}_{\mathrm{i}} \mathrm{h} / \mathrm{kBT}\right)
$$

\section{Results and Discussion}

Determination of modification degree with NPC-PEG: determination of modification degree was based on the ratio of lysine residues of the enzyme before and after modification. Modification of the native enzyme with NPC-PEG was done in three molar concentration variations ratio of native enzyme with NPC-PEG, i.e. $1: 5 ; 1$ : 10; and $1: 15$. Table 1 shows that the modification of enzyme with NPC-PEG produced modified enzyme with modification degree of $33 \%, 42 \%$, and $75 \%$.

\subsection{The effect of modification toward optimum $\mathrm{pH}$}

This experiment aims to know the stability of protease before and after the addition of NPC-PEG toward $\mathrm{pH}$ variation, and to see wheter there is optimum $\mathrm{pH}$ shifting. The effect of addition of NPC-PEG toward optimum $\mathrm{pH}$ of protease can be seen in Figure 1. This figure shows that the eznyme before modificaiton has optimum $\mathrm{pH}$ 6.5 ; and after being modified with NPC-PEG $(33 \%, 42 \%$, and $75 \%)$ the optimum $\mathrm{pH}$ was also 6.5 , so there was not optimum $\mathrm{pH}$ change before and after modificaton. 
Based on Figure 1, the activity of all modified enzymes with NPC-PEG at various $\mathrm{pH}$ are more stable than that of native one, especially at more basic $\mathrm{pH}$. The increase of enzyme stability of the modified enzyme towards $\mathrm{pH}$ was predicted because free $\mathrm{NH}_{2}$ group at $\mathrm{R}$ group at the surface of the enzyme bind to NPC-PEG so the charge change at enzyme structure occurred. Zubay stated that the effect of $\mathrm{pH}$ on activity of some enzymes depend on the $\mathrm{pK}_{\mathrm{a}}$ value and group ionization on the enzyme as well the substrate involve in the reaction (Zubay, 1983). Whilst the $\mathrm{pH}$ sensitivity of the enzyme generally indicated by the group which can be ionized at reaction site of the enzyme. This ionized group is determinator of some tertier structural change on the enzyme which affect the eznyme active site.

\subsection{The effect of modification toward optimum temperature}

$\%$ activity of protease obtained from B. subtilis ITBCCB148 before and after modification with NPC-PEG at various $\mathrm{pH}$ can be seen in Figure 2. This figure indicated that before the addition of NPC-PEG, the protease has optimum temperatature of $60^{\circ} \mathrm{C}$. After being modified, the optimum temperature was shifted from $60^{\circ} \mathrm{C}$ to $65^{\circ} \mathrm{C}$. The optimum temperature shift on the modified enzyme occured because the NPC-PEG molecule entered the hole to go to the active centre of the enzyme. This condition caused the three dimension structure of the enzyme changed so its activation energy was also changed, as a result this caused the optimum temperature shifted from $60^{\circ} \mathrm{C}$ to $65^{\circ} \mathrm{C}$.

\subsection{The effect of modification toward thermal stability}

The residual activity of the enzyme before and after modification with NPC-PEG (33\%, 42\%, and 75\%) was done by incubating each enzyme at $\mathrm{pH} 6.5$ and temperature of $60^{\circ} \mathrm{C}$ for 360 minutes. The curve of thermal stability test of native and modified enzymes is presented in Figure 3. Figure 3 indicated that the enzyme before modification has residual activity of 5.75\%, while the modified enzyme with NPC-PEG 33\%, NPC-PEG 42\%, and NPC-PEG $75 \%$ has residual activity of $23.97 \%$; $27.61 \%$; and $31.15 \%$, respectively. These results illustrated that there was increase of $\mathrm{pH}$ stability of modified enzyme compared to the native one. Moreover, the higher modification degree on the modified enzyme, the higher residual activity after 360 minutes.

3.4 Rate of thermal inactivation (ki), half-life ( $\left.t^{1 / 2}\right)$ and the energy change due to denaturation ( $\left.\Delta G i\right)$ of native and modified enzymes

The half-life $\left(\mathrm{t}_{1 / 2}\right)$ of all modified enzymes with NPC-PEG was increased. The half-lives of modified enzyme with NPC-PEG 33\%, NPC-PEG 42\%, and NPC-PEG 75\%) were increased 2.06, 2.24 and 2.31 times, respectivel (Table 2). According to Stahl (1999) the enzyme stability toward $\mathrm{pH}$ and temperature was determined by the half-life of the enzyme. The half-lives of modified enzyme with NPC-PEG 33\% has increased from 84.5 minutes to 173.3 minutes, NPC-PEG $42 \%$ from 84.5 minutes to 210 minutes, and NPC-PEG $75 \%$ from 84.5 minutes to 216.6 minutes.

The values of rate of thermal inactivations $\left(\mathrm{k}_{\mathrm{i}}\right)$ of native and modified enzymes are shown in Table 2 and it illustrated the decrease of $\mathrm{k}_{\mathrm{i}}$ value for all modified enzymes. The higher the modification degree used to native enzyme, the smaller the value of $\mathrm{k}_{\mathrm{i}}$ obtained. This indicated the decrease of denaturation rate of the enzyme after modification. The decrease of $\mathrm{k}_{\mathrm{i}}$ is predicted due to the formation of bond between long chain NPC-PEG with $\mathrm{NH}_{2}$ group on the side chain of lysine residue on the surface of the enzyme molecule. This makes the enzyme is less flexible in aqueous solution, which makes the protein unfolding is less and the enzyme stability is increased (Yang et al., 1996).

The energy change due to denaturation $\left(\Delta \mathrm{G}_{\mathrm{i}}\right)$ is shown in Table 2 and it illustrated that $\Delta \mathrm{G}_{\mathrm{i}}$ of modified enzyme was increased compare to that of the native enzyme. The higher the modification degree used, the higher the $\Delta \mathrm{G}_{\mathrm{i}}$ value obtained. This indicated that the modified enzyme with higher modification degree is more rigid and less flexible, so the energy to denaturate the enzyme is also higher. The $\Delta \mathrm{G}_{\mathrm{i}}$ value of the native protease was 106.792 $\mathrm{kJ} \mathrm{mol}^{-1}$, while the modified protease with NPC-PEG $33 \%, 42 \%, 75 \%$ were $108.481 \mathrm{~kJ} \mathrm{~mol}^{-1} ; 109.028 \mathrm{~kJ} \mathrm{~mol}^{-1}$; and $109.113 \mathrm{~kJ} \mathrm{~mol}^{-1}$, respectively.

\section{Conclusions}

Based on the results obtained, the chemical modification of protease with NPC-PEG has successfully increased the stability the protease isolated from local bacteria isolate Bacillus subtilis ITBCCB148 as shown by the increase of their half-lives, optimum temperature and $\Delta \mathrm{G}_{\mathrm{i}}$ although the optimum $\mathrm{pH}$ did not change. The decrease of $k_{i}$ value, increase of half-life and $\Delta \mathrm{G}_{\mathrm{i}}$ indicated that the modified enzymes were more stable than the native one.

\section{Acknowledgments}

The authors would like to thank to The Directorate of Research and Community Services, Directorate General of Higher Education, The Ministry of National Education of Republic of Indonesia that provide fund for this project to be undertaken through Hibah Bersaing XV/2 Research Grant Scheme 2008 with contract number of 010/SP2H/PP/DP2M/III/2008, 6 March 2008 and The Competitive Research Grant for International Publication 2009. 


\section{References}

Chaplin, M.F. and Bucke, C. (1990). Enzyme Technology, Cambridge: Cambridge University Press.

Goddette, D.W., Christianson, T., Ladin, B.F., Lau, M., Mielenz, J.R., Paech, C., Reynolds, R.B., Yang, S.S. and Wilson, C.R. (1993). Strategy and implementation of a system for protein engineering. Journal of Biotechnology, 28 (1): 41-54. doi:10.1016/0168-1656(93)90124-6

Hernaiz, M.J., Montero, J.M.S. and Sinisterra, J.V. (1999). Modification of purified lipases from Candida rugosa with polyethylene glycol: A systematic study. Enzyme and Microbial Technology, 24 (3-4): 181-190. doi:10.1016/S0141-0229(98)00099-4

Janecek, S. (1993). Strategies for Obtaining Stable Enzymes. Process Biochemistry, 28 (7): $435-445$. doi:10.1016/0032-9592(93)85026-C

Kazan, D., Ertan, H. and Erarslan, A. (1997). Stabilization of Escherichia coli Penicilin G Acylase Against Thermal Inactivation by Cross-linking with Dextran Dialdehyde Polymers. Applied Microbiology and Biotechnolgy, 48 (2): 191-197. DOI: 10.1007/s002530051037

Lowry, O.H., Rosebrough, N.J., Farr, A.L. and Randall, R.J. (1951). Protein measurment with the Folin phenol reagent. Journal of Biological Chemistry, 193: 265 -275.

Mozhaev, V.V. and Martinek, K. (1984). Structure Stability Relationship in Proteins: New Approaches to Stabilizing Enzymes. Enzyme and Microbial Technology, 6 (2): 50-59. doi:10.1016/0141-0229(84)90034-6

Rao, M.B., Tanksale, A.M., Gate, M.S. and Desphande, V.V. (1998). Molecular and Biotechnology aspects of Microbial Proteases. Microbiology and Molecular Biology Reviews, 62 (3): 597-628. PMID: 9729602.

Stahl, S. (1999). Thermophilic Microorganisms: The Biological Background for Thermophily and Thermoresistance of Enzymes in Thermostability of Enzymes (Gupta, M.N. ed.), New Delhi: Springer Verlag, pp. 59-60.

Synder, S.L. and Sobocinski, P.Z. (1975). An improved 2,4,6-trinitrobenzenesulfonic acid method for the determination of amines. Analytical Biochemistry, 64 (1): 284-288. PMID:1137089.

Vieille, C. and Zeikus, J.G. (1996). Thermozymes: Identifying molecular determinant of protein structural and functional stability. Trends in Biotechnology, 14 (6): 183-189. doi:10.1016/0167-7799(96)10026-3

Yamaguchi, T., Yamashita, Y., Takeda, I. and Kiso, H. (1982). Proteolytic enzymes in green asparagus, kiwi fruit and miut: occurence and partial characterization. Agricultural and Biological Chemistry, 46 (8): $1983-1986$. doi:10.1271/bbb1961.46.1983

Yandri (2004). Characterization and Chemical Modification of $\alpha$-amilase Enzyme from dari Locale Bacteria Isolate Bacillus subtilis ITBCCB148. Ph.D. Disertation, Bandung Institute of Technology, Bandung, Indonesia. (Indonesian).

Yandri, Suhartati, T. and Herasari, D. (2007). Purification and Characterization of thermostable from locale bacteria isolate Bacillus subtilis ITBCCB148. Jurnal Sains MIPA (Special Edition), 13 (2): 100- 106 (Indonesian).

Yandri, Suhartati, T., Herasari, D. and Hadi, S. (2008). The Chemical Modification of Protease Enzyme Isolated from Locale Bacteria, Bacillus subtilis ITBCCB148, with Polyethylenglycol Cyanuric Chloride. European Journal of Scientific Research, 23 (1): 177-186.

Yang, Z., Domach, M., Auger, R., Yang, F.X. and Russel, A.J. (1996). Polyethylene glycol-induced stabilization of subtilisin. Enzyme and Microbial Technology, 18 (2): 82-89. doi:10.1016/0141-0229(95)00073-9

Zubay, G. (1983). Biochemistry, Collier Macmillan, Canada, 277 pages.

Table 1. Determination of modification degree with TNBS

\begin{tabular}{|l|c|c|}
\hline \multicolumn{1}{|c|}{ Sample } & $\Delta$ A 420nm & Modification (\%) \\
\hline Native enzyme & 0.012 & 0 \\
\hline NPC-PEG 1 $: 5$ & 0.008 & 33 \\
\hline NPC-PEG 1 $: 10$ & 0.007 & 42 \\
\hline NPC-PEG 1 $: 15$ & 0.003 & 75 \\
\hline
\end{tabular}


Table 2. The values of Rate of thermal inactivation (ki), half-life $\left(\mathrm{t}^{1 / 2}\right)$ and the energy change due to denaturation $\left(\Delta \mathrm{G}_{\mathrm{i}}\right)$ of native and modified enzymes

\begin{tabular}{|l|c|c|c|}
\hline \multicolumn{1}{|c|}{ Enzyme } & $\mathrm{k}_{\mathrm{i}}\left(\mathrm{min}^{-1}\right)$ & $\mathrm{t}_{1 / 2}(\mathrm{~min})$. & $\mathrm{G}_{\mathrm{i}}\left(\mathrm{kJ} \mathrm{mole}^{-1}\right)$ \\
\hline Native enzyme & 0.0082 & 84.5 & 106.508 \\
\hline NPC-PEG 33\% & 0.004 & 173.3 & 108.481 \\
\hline NPC-PEG 42\% & 0.0033 & 210 & 109.028 \\
\hline NPC-PEG 75\% & 0.0032 & 216.6 & 109.113 \\
\hline
\end{tabular}

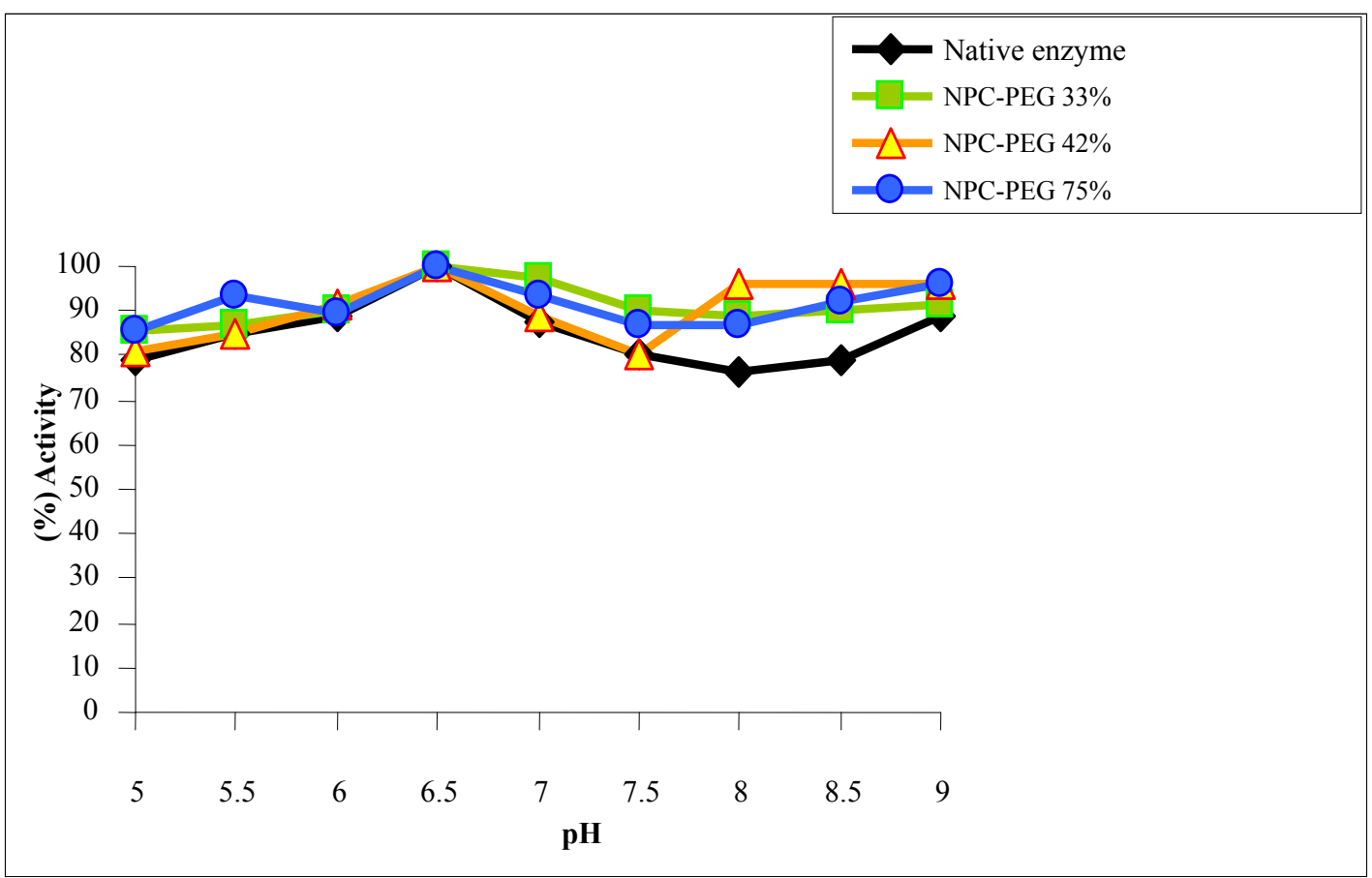

Figure 1. The relationship of $\mathrm{pH}$ and the activity of native protease and modified protease with NPC-PEG (33\%, $42 \%$ and $75 \%$ ) 


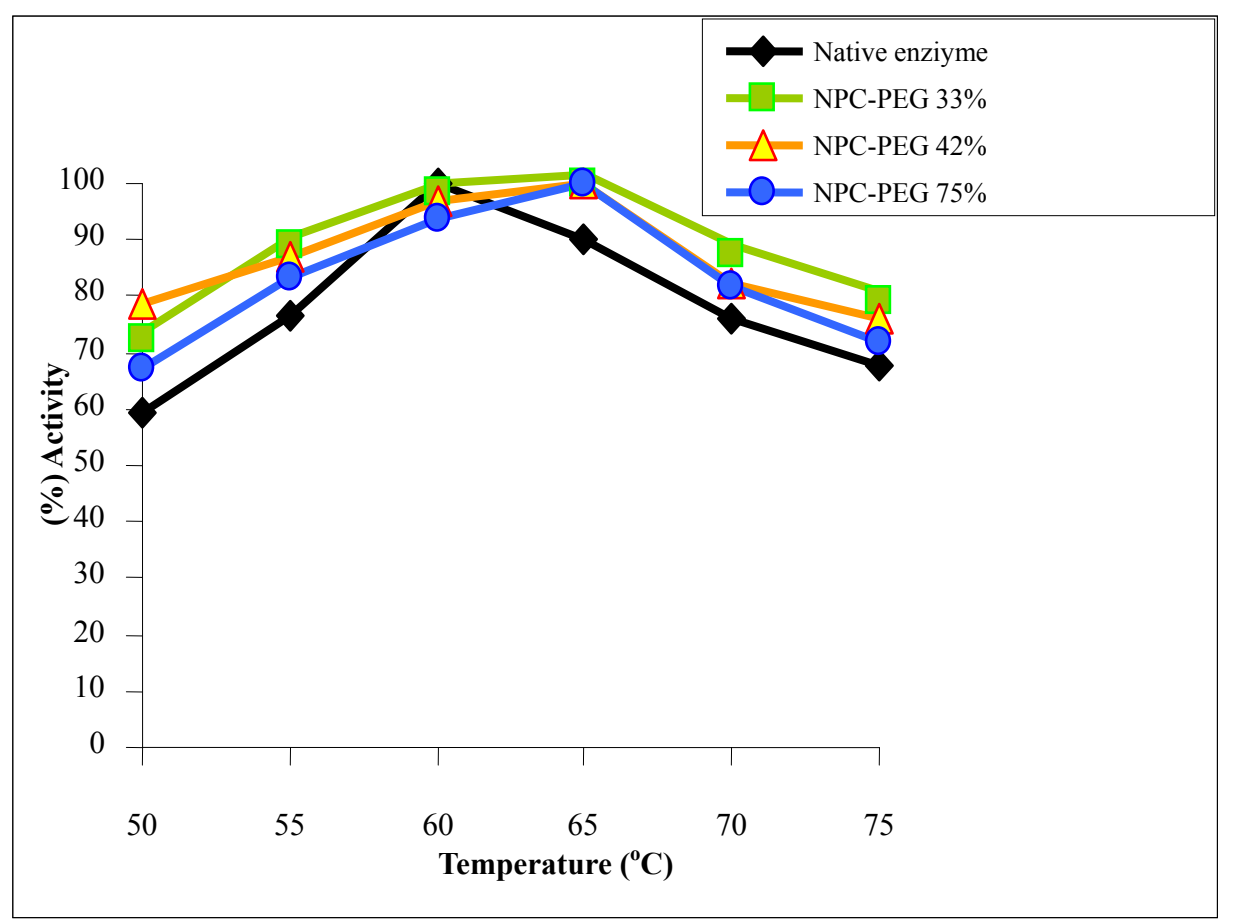

Figure 2. The relationship between temperature and protease activity of native and modified enzyme with NPC-PEG $(33 \%, 42 \%$ and $75 \%)$

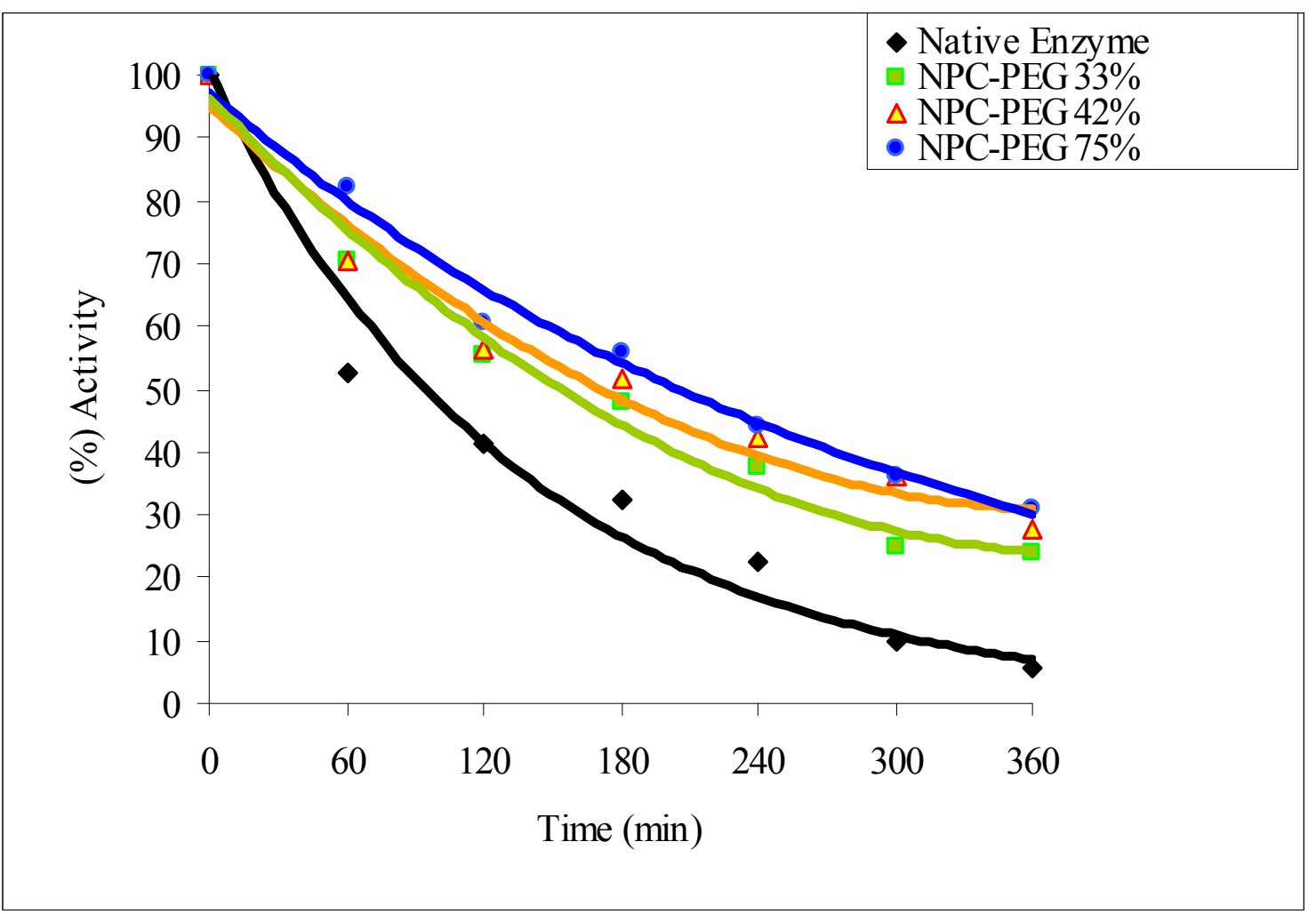

Figure 3. Thermal stability presented by graph of residual activity (\%) of native enzyme and modified enzyme with NPC-PEG $(33 \%, 42 \%$ and $75 \%)$ at $\mathrm{pH} 6.5$ and temperature $60^{\circ} \mathrm{C} v$ s time 